\title{
Sistem Pendukung Keputusan Kelayakan Sertifikasi Guru Pada SD Negeri 016402 Bandar Pasir Mandoge Menggunakan Metode SAW
}

\author{
Yati Rosella Gultom ${ }^{*}$, Zulfi Azhar ${ }^{2}$ \\ 1,2 Program Studi Sistem Informasi, STMIK Royal Kisaran, Indonesia \\ ${ }^{2}$ zulfi_azhar@yahoo.co.id
}

\begin{tabular}{l}
\hline open \\
Histori Artikel: \\
Diajukan: 20 June 2021 \\
Disetujui: 25 June 2021 \\
Dipublikasi: 30 June 2021 \\
\hline Kata Kunci: \\
Component; formatting; \\
style; styling; insert \\
(minimal 5 words) \\
\hline Digital Transformation \\
Technology (Digitech) is an \\
Creative Commons License This \\
work is licensed under a \\
Creative Commons Attribution- \\
NonCommercial 4.0 \\
International (CC BY-NC 4.0).
\end{tabular}

\begin{abstract}
Abstrak
SD Negeri 016402 Bandar Pasir Mandoge sering menghadapi kesulitan dalam menentukan layak atau tidaknya seorang guru dalam mengikuti proses sertifikasi dengan memenuhi nilai kriteria yang sudah ditentukan. Jumlah guru yang banyak, maka proses penilaiannya memerlukan waktu yang cukup lama dalam mendapatkan hasil penilaiannya. Disamping itu pihak sekolah tersebut tidak memiliki sarana untuk melakukan evaluasi terhadap pencapaian kriteria pada masing-masing guru terkait dengan sertifikasi. Berdasarkan permasalahan tersebut, maka diperlukan untuk membangun suatu sistem informasi yang sesuai yang dapat membantu pihak sekolah SDN 016402 Bandar Pasir Mandoge dalam menentukan kelayakan guru dalam mendapatkan sertifikasi guru. untuk meningkatkan mutu guru dengan syarat dan kriteria yang telah ditentukan. Metode penelitian dilakukan dengan observasi di lingkungan sekolah dengan analisis menggunakan metode sistem pendukung keputusan Simple Additive Weighting (SAW). Sistem aplikasi ini dapat mempercepat proses penentuan Guru-Guru yang berhak mengajukan sertifikasi dengan lebih cepat dan akurat. Sistem dapat mengurangi kesalahan dalam penentuan Guru-Guru yang berhak mengajukan sertifikasi.
\end{abstract}

\section{PENDAHULUAN}

Teknologi Informasi sangat bermanfaat diberbagai sektor pekerjaan. Salah satu sektor yang sangat membutuhkan pemanfaatan teknologi informasi ini adalah pada sektor pendidikan. Pada sektor pendidikan perananan sistem informasi dapat berfungsi sebagai alat yang salah satunya digunakan untuk mengolah data untuk penggunaan sertifikasi guru. Sertifikasi Guru merupakan proses pemberian sertifikat kepada guru yang telah memenuhi standar professional dengan menciptakan sistem dan praktik pendidikan yang berkualitas .

Kompetensi profesi pendidikan meliputi kompetensi kemampuan mengelola pembelajaran peserta didik yang meliputi pemahaman terhadap peserta didik, perencanaan dan pelaksanaan pembelajaran, evaluasi hasil belajar, dan pengembangan peserta didik untuk mengaktualisasi berbagi potensi yang dimiliki, kompetensi kepribadian, kompetensi sosial, dan kompetensi professional. Kompetensi kepribadian adalah kepribadian pendidik yang mantap, stabil, dewasa, arif, dan berwibawa, menjadi teladan bagi peserta didik, dan berahlak mulia. Kompetensi sosial adalah kemampuan pendidik, tenaga kependidikan, orang tua/wali peserta didik, dan masyarakat. Kompetensi profesional adalah kemampuan pendidik dalam penguasaan materi pembelajaran secara luas dan mendalam yang memungkinkan membimbing peserta didik memperoleh kompetensi yang ditetapkan. Tujuan dari Sertifikasi Guru yaitu menentukan kelayakan guru dalam melaksanakan tugas sebagai agen pembelajaran dan mewujudkan tujuan pendidikan nasional, meningkatkan proses dan mutu hasil pendidikan, meningkatkan martabat guru dan meningkatkan profesionalitas guru .

Saat ini SD Negeri 016402 Bandar Pasir Mandoge sering menghadapi kesulitan dalam menentukan layak atau tidaknya seorang guru dalam mengikuti proses sertifikasi dengan memenuhi nilai kriteria yang sudah ditentukan. Selama ini proses penilaian para guru dilakukan secara manual, dengan cara melihat dari kedisplinan dan tanggung jawab para guru dalam bekerja. Jumlah guru yang banyak, maka proses penilaiannya memerlukan waktu yang cukup lama dalam mendapatkan hasil penilaiannya. Disamping itu pihak sekolah tersebut tidak memiliki sarana untuk melakukan evaluasi terhadap pencapaian kriteria pada masing-masing guru terkait dengan sertifikasi. Berdasarkan permasalahan tersebut, maka diperlukan untuk membangun suatu sistem informasi yang sesuai yang dapat membantu pihak sekolah SDN 016402 Bandar Pasir Mandoge dalam menentukan kelayakan guru dalam mendapatkan sertifikasi guru. untuk meningkatkan mutu guru dengan syarat dan kriteria yang telah ditentukan. 


\section{STUDI LITERATUR}

Pendidikan yang bermutu merupakan syarat utama untuk mewujudkan kehidupan bangsa yang maju, modern dan sejahtera. Sejarah perkembangan dan pembangunanbangsa-bangsa mengajarkan pada kita bahwa bangsa yang maju, modern, makmur, dan sejahtera adalah bangsa-bangsa yang memiliki sistem dan praktik pendidikan yang bermutu(Tusriyanto 2014).

Guru dan dosen dapat dikatakan sebagai pemegang peran yang sangat penting dan strategis dalam usaha meningkatkan mutu pendidikan di setiap satuan pendidikan. Berapa pun besarnya investasi yang ditanamkan untuk memperbaiki mutu pendidikan, tanpa kehadiran guru dan dosen yang kompeten, profesional, bermartabat, dan sejahtera dapat dipastikan tidak akan tercapai tujuan yang diharapkan(Scobee and Slaughter 1944)

Guru profesional harus mampu menciptakan pembelajaran kreatif dan menyenangkan. Dua kata terakhir "kreatif" dan "menyenangkan" diungkapkan dengan kata hubung "dan". Menurut logika bahasa kata "dan" mencakup dua hal yang tidak boleh berpisah. Kreatif dapat bermakna variatif, inovatif, atau baru dan harus dinikmati secara menyenangkan oleh pebelajar. Tuntutan kreatif dan menyenangkan terkesan sederhana tetapi dalam aplikasinya bukanlah hal yang gampang(Malik 2011).

Dalam undang-undang no.14 tahun 2005 tentang guru dan dosen dikemukakan bahwa sertifikasi adalah proses pemberian sertifikat pendidik untuk guru dan dosen. Sedangkan sertifikat pendidik adalah bukti formal sebagai pengakuan yang diberikan kepada guru dan dosen sebagai tenaga profesional(Juwita et al. 2020)(Latiana 2010)(Yusuf, Bekti, and Sukarno 2017).

Sertifikasi guru adalah proses pemberian sertifikat pendidik kepada guru. Sertifikat pendidik diberikan kepada guru yang telah memenuhi standar profesional guru. Guru profesional merupakan syarat mutlak

untuk menciptakan pendidikan yang berkualitas. Sertifikat pendidik adalah sebuah sertifikat yang ditandatangani oleh perguruan tinggi penyelenggara sertifikasi sebagai bukti formal pengakuan profesionalitas guru(Siahaan and Martiningsih 2018).

Sertifikasi guru juga dapat diartikan sebagai suatu proses pemberian pengakuan bahwa seorang guru telah memiliki kompetensi untuk melaksanakan tugas kependidikan pada satuan pendidikan tertentu, setelah lulus ujikompetensi yang diselenggarakan oleh lembega sertifikasi(Andi et al. 2017).

Sebagai tenaga pendidik, guru merupakan komponen yang paling menentukan bagi terciptanya proses dan hasil belajar siswa yang berkualitas untuk pencapaian tujuan institusi pendidikan sekolah. Kedudukan guru dalam pembelajaran merupakan sesuata hal yang tidak bisa digantikan oleh teknologi canggih apapun, karena keberadaan teknologi canggih tetap membutuhkan guru dalam mengoperasionalkannya. Di tangan guru yang profesional, fasilitas dan sarana yang kurang memadai bisa di atasi dan ditutupi, tetapi sebaliknya di tangan pendidik yang kurang profesional, maka sarana dan fasilitas yang mencukupi tidak mampu termanfaatkan secara baik sehingga berdampak pada prestasi belajar siswa yang tidak meningkat. Jadi betapapun canggih dan baiknya teknologi serta kurikulum yang disusun, namun pada akhirnya keberhasilan pendidikan sangat ditentukan oleh tenaga pendidik yang profesional(Adhar 2013).

Kinerja Guru pada dasarnya merupakan kinerja atau unjuk kerja yang dilakukan oleh guru dalam melaksanakan tugasnya sebagai pendidik . Kinerja guru sangat menentukan kualitas hasil pendidikan, karena guru merupakan fihak yang paling banyak bersentuhan langsung dengan siswa dalam proses pendidikan/pembelajaran di lembaga pendidikan Sekolah(Qowaid 2015).

Decision Support System (DSS) sebagai sistem berbasis komputer yang dapat memberikan rekomendasi untuk proses pengambilan keputusan. DSS adalah sistem informasi berbasis komputer yang adaptif, interaktif, fleksibel, dan terspesialisasi yang dikembangkan untuk mendukung solusi atas permasalahan yang dihadapi manajemen guna meningkatkan kualitas pengambilan keputusan(Kurniawan 2018).

Metode SAW sering juga dikenal dengan metode penjumlahan berbobot. Konsep dasar metode SAW adalah mencari penjumlahan terbobot dari peringkat kinerja untuk setiap alternatif pada semua atribut. Metode SAW membutuhkan proses normalisasi matriks keputusan (X) ke skala yang dapat dibandingkan dengan semua peringkat alternatif yang ada. Metode ini merupakan metode yang paling dikenal dan paling banyak digunakan dalam menangani situasi MADM (multiple attribute decision making). Metode ini mengharuskan pengambil keputusan untuk menentukan bobot untuk setiap atribut. Skor total untuk suatu alternatif diperoleh dengan menjumlahkan semua hasil perkalian antara peringkat (yang dapat dibandingkan antar atribut) dan bobot setiap atribut. Rating setiap atribut harus bebas dimensi, artinya telah melewati proses normalisasi sebelumnya(Zul et al. 2016)(Hermanto and Izzah 2018)(Pendukung et al. 2018)(Sistem 2017)(Ardi et al. 2019)(Harsiti and Aprianti 2017)(Priatna and Nugroho 2019)

\section{Metode Simple Additive Weighting (SAW).}

Metode simple additive weighting sering juga dikenal dengan istilah metode penjumlahan terbobot. Konsep dasar SAW adalah mencari penjumlahan terbobot dari kinerja setiap alternatif pada semua atribut (Rina Hanasah, 2013). Metode SAW membutuhkan proses normalisasi matriks keputusan (X) ke suatu skala yang dapat dibandingkan dengan semua rating alternatif yang ada. Dimana rij adalah rating kinerja 
ternormalisasi dari alternatif Ai pada atribut $\mathrm{Cj}: \mathrm{i}=1,2, \ldots, \mathrm{m}$ dan $\mathrm{j}=1,2, \ldots, \mathrm{n}$. Nilai preferensi untuk setiap alternatif (Vi) diberikan pada rumus di bawah ini :

Rumus untuk melakukan normalisasi adalah:

$$
r i j=\left\{\begin{array}{l}
\frac{x i j}{\operatorname{Max} x i j} \text { If } j \text { is a benefit attribute } \\
\frac{\text { Min } x i j}{x i j} \text { If } j \text { is a cost attribute (cost) }
\end{array}\right.
$$

Dimana :

rij = peringkat kinerja yang dinormalisasi

Max xij = nilai maksimum setiap baris dan kolom

Min $x i j=$ nilai minimum setiap baris dan kolom

xij = baris dan kolom matrik

$V i=\sum_{j=1}^{n} w j r i j$

Keterangan :

$\mathrm{Vi}=$ ranking untuk setiap alternatif.

$\mathrm{Wj}=$ nilai bobot dari setiap kriteria.

rij = nilai rating kinerja ternormalisasi.

Langkah selanjutnya yang dilakukan yaitu penghitungan matriks keputusan ternormalisasi dengan menggunakan rumus Nilai Vi lebih besar mengindikasikan bahwa alternatif Ai lebih terpilih.

\section{METODE}

Metode penelitian yang digunakan adalah sebagai berikut :

a. Observasi ( Obsevation )

Melakukan observasi atau penulisan secara berkala dan terus menerus ke lingkungan sekolah sepenuhnya dan terkonsentrasi pada observasi atau pada penelitian.

b. Analisa ( Analysis )

Menganalisa kebutuhan program dan melakukan perancangan antarmuka dari sistem yang akan dibuat.

c. Desain ( Design )

Merancang perangkat lunak pada program yang akan didesain pada sistem pendukung keputusan untuk kelayakan sertifikasi guru.

d. Implementasi ( Implementation )

Pengujian dilakukan dengan mencoba aplikasi perangkat lunak sistem pendukung keputusan yang telah dibuat. Apabila terjadi kesalahan atau kekurangan dalam aplikasi tersebut, maka akan dilakukan pemograman ulang.

e. Studi Pustaka ( Literature Review)

Metode Studi Pustaka, yaitu dengan membaca beberapa literatur - literatur dan referensi - referensi mengenai sistem pendukung keputusan dan metode Simple Additive Weighting (SAW).yang diperoleh dari buku - buku dan dari berbagai sumber serta informasi dari internet.

\section{HASIL}

Penilaian dilakukan dengan melihat nilai-nilai terhadap indikator yang berpengaruh seperti Surat Keterangan (SK), umur, masa kerja, golongan, surat kesehatan dan pendidikan terakhir. Selanjutnya masingmasing indikator tersebut dianggap sebagai kriteria yang akan dijadikan sebagai faktor untuk menentukan rekomendasi penentuan guru-guru sesuai dengan yang diharapkan oleh Kepala Dinas Pendidikan Kabupaten Asahan. Variabel yang digunakan dalam penelitian ini adalah Surat Keterangan (SK), Umur, Masa Kerja, Golongan, Surat Kesehatan dan Pendidikan Terakhir. 
Tabel 1

Kriteria Guru Yang Berhak Mengajukan Sertifikasi

\begin{tabular}{lc}
\hline Kriteria & Keterangan \\
\hline C1 & Surat Keterangan Kerja \\
C2 & Umur \\
C3 & Masa Kerja \\
C4 & Golongan \\
C5 & Surat Kesehatan \\
C6 & Pendidkan Terakhir \\
\hline
\end{tabular}

Tabel 2

Nilai Bobot

\begin{tabular}{lc}
\hline Definisi & Bobot \\
\hline Tidak Ada Nilai & 0 \\
Sangat Rendah (SR) & 0,25 \\
Rendah (R) & 0,34 \\
Cukup (C) & 0,5 \\
Sangat Cukup (SC) & 0,67 \\
Tinggi (T) & 0,75 \\
Sangat Tinggi (ST) & 1 \\
\hline
\end{tabular}

Tabel 3

Kriteria Surat Keterangan Mengajar

\begin{tabular}{lccc}
\hline \hline SK Mengajar (C1) & Nilai & Bobot & Definisi \\
\hline Tidak Ada & $0 / 1$ & 0 & Tidak Ada Nilai \\
Ada & $1 / 1$ & 1 & Sangat Tinggi \\
\hline
\end{tabular}

Tabel 4

Kriteria Umur

\begin{tabular}{lccc}
\hline \hline Umur (C2) & Nilai & Bobot & Definisi \\
\hline $\mathrm{C} 2=30$ & $0 / 3$ & 0 & Tidak Ada Nilai \\
$\mathrm{C} 2=40$ & $1 / 3$ & 0,34 & Rendah \\
$\mathrm{C} 2=50$ & $2 / 3$ & 0,67 & Sangat Cukup \\
$\mathrm{C} 2=60$ & $3 / 3$ & 1 & Sangat Tinggi \\
\hline & &
\end{tabular}

Kriteria Masa Kerja

\begin{tabular}{lccc}
\hline \hline Masa Kerja $(\mathrm{C} 3)$ & Nilai & Bobot & Definisi \\
\hline C3 $<=5$ Tahun & $0 / 4$ & 0 & Tidak Ada Nilai \\
C3 = 6-10 Tahun & $1 / 4$ & 0,25 & Sangat Rendah \\
C3 $=11-15$ Tahun & $2 / 4$ & 0,5 & Cukup \\
C3 = 16-20 Tahun & $3 / 4$ & 0,75 & Tinggi \\
C3 $>$ 20 Tahun & $4 / 4$ & 1 & Sangat Tinggi \\
\hline
\end{tabular}


Tabel 6

Kritera Golongan

\begin{tabular}{lccc}
\hline \hline Golongan (C4) & Nilai & Bobot & Definisi \\
\hline III A & $0 / 3$ & 0 & Tidak Ada Nilai \\
III B & $1 / 3$ & 0,34 & Rendah \\
III C & $2 / 3$ & 0,67 & Sangat Cukup \\
IV A & $3 / 3$ & 1 & Sangat Tinggi \\
\hline
\end{tabular}

Tabel 7

Kriteria Surat Kesehatan

\begin{tabular}{lccc}
\hline Surat Kesehatan (C5) & Nilai & Bobot & Definisi \\
\hline Tidak Sehat & $0 / 1$ & 0 & Tidak Ada Nilai \\
Sehat & $1 / 1$ & 1 & Sangat Tinggi \\
\hline
\end{tabular}

Tabel 8

Kriteria Pendidikan Terakhir

\begin{tabular}{lccc}
\hline \hline SK Mengajar & Nilai & Bobot & Definisi \\
\hline D-I & $0 / 4$ & 0 & Tidak Ada Nilai \\
D-II & $1 / 4$ & 0,25 & Sangat Rendah \\
D-III & $2 / 4$ & 0,5 & Cukup \\
S-1 & $3 / 4$ & 0,75 & Tinggi \\
S-2 & $4 / 4$ & 1 & Sangat Tinggi \\
\hline
\end{tabular}

Tabel 9

Data Alternatif Guru Sertifikasi

\begin{tabular}{lllccccc}
\hline \hline No & Alternatif & C1 & C2 & C3 & C4 & C5 & C6 \\
\hline 1 & Agus Saputra & Ada & 40 & 7 & III C & Sehat & S-1 \\
2 & Jailani & Ada & 35 & 10 & III C & Tidak Sehat & S-1 \\
3 & M. Thalib & Ada & 48 & 12 & III C & Sehat & S-1 \\
4 & Samsuar & Ada & 50 & 9 & III A & Tidak Sehat & S-1 \\
5 & Erni & Ada & 49 & 20 & III B & Sehat & S-1 \\
6 & Nori Mentari & Ada & 30 & 10 & III A & Sehat & S-1 \\
\hline
\end{tabular}

Tabel 10

Rating Kecocokan Dari Setiap Alternatif Pada Setiap Kriteria

\begin{tabular}{cccccccc}
\hline \hline No & Alternatif & C1 & C2 & C3 & C4 & C5 & C6 \\
\hline 1 & A1 & 1 & 0,34 & 0,25 & 0,67 & 1 & 0,75 \\
2 & A2 & 1 & 0,34 & 0,25 & 0,67 & 0 & 0,75 \\
3 & A3 & 1 & 0,67 & 0,5 & 0,67 & 1 & 0,75 \\
4 & A4 & 1 & 0,67 & 0,25 & 0,67 & 0 & 0,75 \\
5 & A5 & 1 & 0,67 & 0,75 & 0,34 & 1 & 0,75 \\
6 & A6 & 1 & 0 & 0,5 & 0 & 1 & 0,75 \\
\hline
\end{tabular}

Pengambilan keputusan memberikan bobot berdasarkan tingkat kepentingan masing-masing kriteria yang dibutuhkan adalah sebagai berikut :

Vektor bobot : $\mathrm{W}=[1 ; 0.67 ; 0.75 ; 0.67 ; 1 ; 0.75]$

Membuat matriks keputusan X, dibuat dari tabel kecocokan sebagai berikut : 


$$
R=\left[\begin{array}{cccccc}
1 & 0.34 & 0.25 & 0.67 & 1 & 0.75 \\
1 & 0.34 & 0.25 & 0.67 & 0 & 0.75 \\
1 & 0.67 & 0.5 & 0.67 & 1 & 0.75 \\
1 & 0.67 & 0.25 & 0.67 & 0 & 0.75 \\
1 & 0.67 & 0.75 & 0.34 & 1 & 0.75 \\
1 & 0 & 0.5 & 0 & 1 & 0.75
\end{array}\right]
$$

Langkah selanjutnya adalah dengan melakukan normalisasi matriks $\mathrm{X}$ untuk menghitung nilai masing-masing kriteria.

1. Normalisasi

Fungsi dari normalisasi adalah untuk menghitung rating kinerja ternormalisasi dari alternatif diatas dengan menggunakan rumus :

$$
\frac{X_{i j}}{\operatorname{MAXX}_{i j}}
$$

Maka, akan didapat nilai sebagai berikut :

Untuk Kriteria (C1) :

$$
\begin{aligned}
& r_{11}=\frac{1}{\max \{1 ; 1 ; 1 ; 1 ; 1 ; 1\}}=\frac{1}{1}=1 \\
& r_{21}=\frac{1}{\max \{1 ; 1 ; 1 ; 1 ; 1 ; 1\}}=\frac{1}{1}=1 \\
& r_{31}=\frac{1}{\max \{1 ; 1 ; 1 ; 1 ; 1 ; 1\}}=\frac{1}{1}=1 \\
& r_{41}=\frac{1}{\max \{1 ; 1 ; 1 ; 1 ; 1 ; 1\}}=\frac{1}{1}=1 \\
& r_{51}=\frac{1}{\max \{1 ; 1 ; 1 ; 1 ; 1 ; 1\}}=\frac{1}{1}=1 \\
& r_{61}=\frac{1}{\max \{1 ; 1 ; 1 ; 1 ; 1 ; 1\}}=\frac{1}{1}=1
\end{aligned}
$$

Untuk Kriteria (C2) :

$$
\begin{aligned}
& r_{12}=\frac{0.34}{\max \{0.34 ; 0.34 ; 0.67 ; 0.67 ; 0.67 ; 0\}}=\frac{0.34}{0.67}=0.50 \\
& r_{22}=\frac{0.34}{\max \{0.34 ; 0.34 ; 0.67 ; 0.67 ; 0.67 ; 0\}}=\frac{0.34}{0.67}=0.50 \\
& r_{32}=\frac{0.67}{\max \{0.34 ; 0.34 ; 0.67 ; 0.67 ; 0.67 ; 0\}}=\frac{0.67}{0.67}=1 \\
& r_{42}=\frac{0.67}{\max \{0.34 ; 0.34 ; 0.67 ; 0.67 ; 0.67 ; 0\}}=\frac{0.67}{0.67}=1 \\
& r_{52}=\frac{0.67}{\max \{0.34 ; 0.34 ; 0.67 ; 0.67 ; 0.67 ; 0\}}=\frac{0.67}{0.67}=1 \\
& r_{62}=\frac{0}{\max \{0.34 ; 0.34 ; 0.67 ; 0.67 ; 0.67 ; 0\}}=\frac{0}{0.67}=0
\end{aligned}
$$

Untuk Kriteria (C3) :

$$
\begin{aligned}
& r_{13}=\frac{0.25}{\max \{0.25 ; 0.25 ; 0.5 ; 0.25 ; 0.75 ; 0.5\}}=\frac{0.25}{0.75}=0.34 \\
& r_{23}=\frac{0.25}{\max \{0.25 ; 0.25 ; 0.5 ; 0.25 ; 0.75 ; 0.5\}}=\frac{0.25}{0.75}=0.34
\end{aligned}
$$




$$
\begin{aligned}
& r_{33}=\frac{0.5}{\max \{0.25 ; 0.25 ; 0.5 ; 0.25 ; 0.75 ; 0.5\}}=\frac{0.5}{0.75}=0.67 \\
& r_{43}=\frac{0.25}{\max \{0.25 ; 0.25 ; 0.5 ; 0.25 ; 0.75 ; 0.5\}}=\frac{0.25}{0.75}=0.34 \\
& r_{53}=\frac{0.75}{\max \{0.25 ; 0.25 ; 0.5 ; 0.25 ; 0.75 ; 0.5\}}=\frac{0.75}{0.75}=1 \\
& r_{63}=\frac{0.5}{\max \{0.25 ; 0.25 ; 0.5 ; 0.25 ; 0.75 ; 0.5\}}=\frac{0.5}{0.75}=0.67
\end{aligned}
$$

Untuk Kriteria (C4) :

$$
\begin{aligned}
& r_{14}=\frac{0.67}{\max \{0.67 ; 0.67 ; 0.67 ; 0.67 ; 0.34 ; 0\}}=\frac{0.67}{0.67}=1 \\
& r_{24}=\frac{0.67}{\max \{0.67 ; 0.67 ; 0.67 ; 0.67 ; 0.34 ; 0\}}=\frac{0.67}{0.67}=1 \\
& r_{34}=\frac{0.67}{\max \{0.67 ; 0.67 ; 0.67 ; 0.67 ; 0.34 ; 0\}}=\frac{0.67}{0.67}=1 \\
& r_{44}=\frac{0.67}{\max \{0.67 ; 0.67 ; 0.67 ; 0.67 ; 0.34 ; 0\}}=\frac{0.67}{0.67}=1 \\
& r_{54}=\frac{0.34}{\max \{0.67 ; 0.67 ; 0.67 ; 0.67 ; 0.34 ; 0\}}=\frac{0.34}{0.67}=0.50 \\
& r_{64}=\frac{0}{\max \{0.67 ; 0.67 ; 0.67 ; 0.67 ; 0.34 ; 0\}}=\frac{0}{0.67}=0
\end{aligned}
$$

Untuk Kriteria (C5) :

$$
\begin{aligned}
& r_{15}=\frac{1}{\max \{1 ; 0 ; 1 ; 0 ; 1 ; 1\}}=\frac{1}{1}=1 \\
& r_{25}=\frac{0}{\max \{1 ; 0 ; 1 ; 0 ; 1 ; 1\}}=\frac{0}{1}=0 \\
& r_{35}=\frac{1}{\max \{1 ; 0 ; 1 ; 0 ; 1 ; 1\}}=\frac{1}{1}=1 \\
& r_{45}=\frac{0}{\max \{1 ; 0 ; 1 ; 0 ; 1 ; 1\}}=\frac{0}{1}=0 \\
& r_{55}=\frac{1}{\max \{1 ; 0 ; 1 ; 0 ; 1 ; 1\}}=\frac{1}{1}=1 \\
& r_{35}=\frac{1}{\max \{1 ; 0 ; 1 ; 0 ; 1 ; 1\}}=\frac{1}{1}=1
\end{aligned}
$$

Untuk Kriteria (C6) :

$$
\begin{aligned}
& r_{16}=\frac{0.75}{\max \{0.75 ; 0.75 ; 0.75 ; 0.75 ; 0.75 ; 0.75\}}=\frac{0.75}{0.75}=1 \\
& r_{26}=\frac{0.75}{\max \{0.75 ; 0.75 ; 0.75 ; 0.75 ; 0.75 ; 0.75\}}=\frac{0.75}{0.75}=1 \\
& r_{36}=\frac{0.75}{\max \{0.75 ; 0.75 ; 0.75 ; 0.75 ; 0.75 ; 0.75\}}=\frac{0.75}{0.75}=1 \\
& r_{46}=\frac{0.75}{\max \{0.75 ; 0.75 ; 0.75 ; 0.75 ; 0.75 ; 0.75\}}=\frac{0.75}{0.75}=1 \\
& r_{56}=\frac{0.75}{\max \{0.75 ; 0.75 ; 0.75 ; 0.75 ; 0.75 ; 0.75\}}=\frac{0.75}{0.75}=1 \\
& r_{66}=\frac{0.75}{\max \{0.75 ; 0.75 ; 0.75 ; 0.75 ; 0.75 ; 0.75\}}=\frac{0.75}{0.75}=1
\end{aligned}
$$


Setelah mendapatkan hasil, maka akan dibuatkan matriks normalisasi :

$$
R=\left[\begin{array}{cccccc}
1 & 0.50 & 0.34 & 1 & 1 & 1 \\
1 & 0.50 & 0.34 & 1 & 0 & 1 \\
1 & 1 & 0.67 & 1 & 1 & 1 \\
1 & 1 & 0.34 & 1 & 0 & 1 \\
1 & 1 & 1 & 0.50 & 1 & 1 \\
1 & 0 & 0.67 & 0 & 1 & 1
\end{array}\right]
$$

2. Preferensi (Vi)

Fungsi dari preferensi adalah untuk mencari nilai tertinggi. Selanjutnya akan dibuat perkalian antara matriks $\mathrm{W} * \mathrm{R}$ dengan menggunakan rumus :

$$
\mathrm{V}_{\mathrm{i}}=\sum_{\mathrm{j}=1}^{\mathrm{n}} \mathrm{W}_{\mathrm{j}} \mathrm{R}_{\mathrm{ij}}
$$

Nilai tertinggi dari hasil perkalian tersebut untuk memperoleh alternatif terbaik dengan melakukan perangkingan nilai terbesar. Maka didapat hasil sebagai berikut :

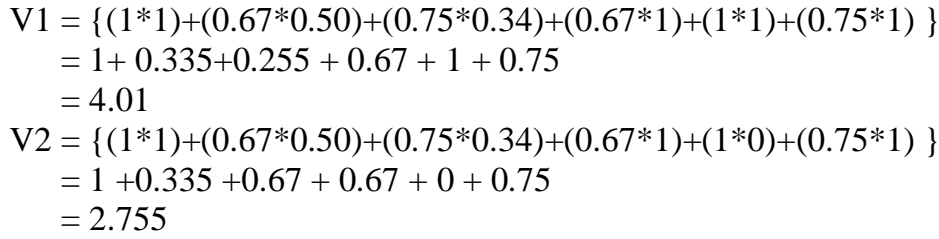

$$
\begin{aligned}
\mathrm{V} 3 & =\{(1 * 1)+(0.67 * 1)+(0.75 * 0.67)+(0.67 * 1)+(1 * 1)+(0.75 * 1)\} \\
& =1+0.67+0.5025+0.67+1+0.75 \\
& =4.5925
\end{aligned}
$$

$$
\begin{aligned}
\mathrm{V} 4 & =\{(1 * 1)+(0.67 * 1)+(0.75 * 0.34)+(0.67 * 1)+(1 * 0)+(0.75 * 1)\} \\
& =1+0.67+0.255+0.67+0+0.75 \\
& =3.345
\end{aligned}
$$

$$
\begin{aligned}
\mathrm{V} 5 & =\{(1 * 1)+(0.67 * 1)+(0.75 * 1)+(0.67 * 0.50)+(1 * 1)+(0.75 * 1)\} \\
& =1+0.67+0.75+0.335+1+0.75 \\
& =4.505
\end{aligned}
$$

$$
\begin{aligned}
\mathrm{V} 6 & =\{(1 * 1)+(0.67 * 0)+(0.75 * 0.67)+(0.67 * 0)+(1 * 0)+(0.75 * 1)\} \\
& =1+0+0.5025+0+0+0.75 \\
& =2.2525
\end{aligned}
$$

Dari perhitungan preferensi alternatif Guru di atas maka keputusan untuk pemilihan dari alternatif dengan nilai minimal = 4 (Sangat Tinggi ), Nilai ini sudah menjadi keputusan Kepala Sekolah SD Negeri 016402 Bandar Pasir Mandoge, maka terpilih sebagai Guru yang berhak menerima Sertifikasi adalah : V3 = M.Thalib ,V5 = Erni dan V1 = Agus Saputra.

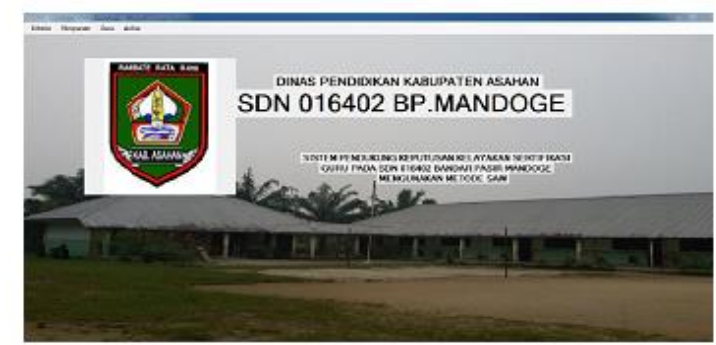

Gambar 1 Form Menu Utama 


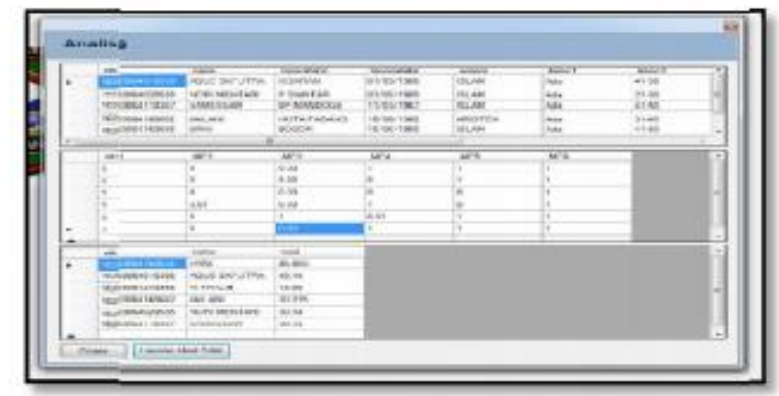

Gambar 2 Form Analisa

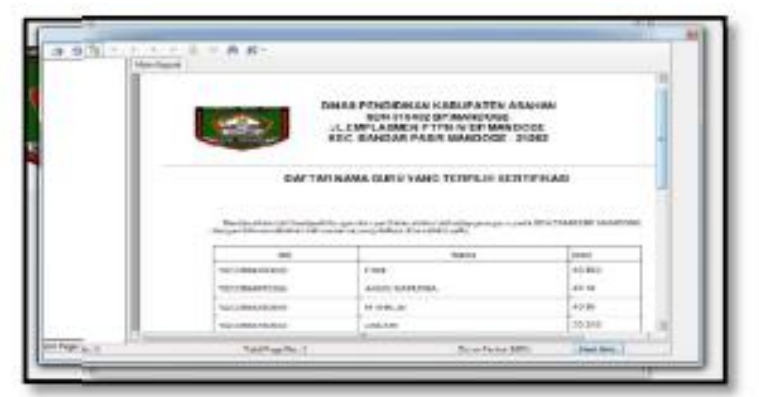

Gambar 3 Form Laporan Hasil Akhir Analisa Penilaian

\section{PEMBAHASAN}

Pengujian sistem pendukung keputusan ini meliputi pengujian identifikasi dengan menggunakan metode Simple Additive Weighting (SAW). Dalam analisa sistem pendukung keputusan penentuan Guru yang berhak mengajukan sertifikasi maka diperlukans suatu aplikasi pendukung keputusan.

Kelemahan Dan Kelebihan Sistem ini adalah :

a. Kelemahan Sistem

Sistem tidak mampu digunakan untuk multi user karena sistem hanya dibangun untuk single user.

Dibutuhkannya seseorang yang ahli dalam pengelolaan sistem tersebut.

b. Kelebihan Sistem

Dapat membuat suatu keputusan dengan memberikan beberapa kriteria dan alternatif.

Memberikan solusi penyelesaian dalam menentukan pilihan dari beberapa kriteria dan alternatif yang ditetapkan.

\section{KESIMPULAN}

Berdasarkan hasil dari sistem yang telah dilakukan, maka kesimpulan akhir ini sebagai berikut:

Nilai ambang batas dari Sistem pendukung keputusan ini di dapat adalah bernilai 2. Sistem dapat mempercepat proses penentuan Guru-Guru yang berhak mengajukan sertifikasi dengan lebih cepat dan akurat. Sistem dapat mengurangi kesalahan dalam penentuan Guru-Guru yang berhak mengajukan sertifikasi. Dengan adanya aplikasi Sistem Pendukung Keputusan ini Guru-Guru yang akan di ajukan sertifikasi lebih akurat dan cepat dengan menggunakan bobot dalam penentuan layak dan tidak layaknya untuk sertifikasi

\section{REFERENSI}

Adhar, Adhar. 2013. "Peran Sertifikasi Untuk Meningkatkan Motivasi Dan Kedisiplinan Guru Dalam Melaksanakan Pembelajaran.” Jurnal Ilmiah Islam Futura 13(1):71.

Andi, Mutmainnah, Fitriani Djollong, Pengaruh Sertifikasi, Guru Terhadap, and Kualitas Mengajar. 2017. "Pengaruh Sertifikasi Terhadap Kualitas Mengajar Guru (." V(September):1-8.

Ardi, Ardi, Dasril Aldo, and Ahmadi Ahmadi. 2019. "Sistem Pendukung Keputusan Menentukan Peserta Jamkesmas Dengan Metode Simple Additive Weighting." Jurnal RESTI (Rekayasa Sistem Dan Teknologi Informasi) 3(2):94-99.

Harsiti, Harsiti, and Henri Aprianti. 2017. "Sistem Pendukung Keputusan Pemilihan Smartphone Dengan Menerapkan Metode Simple Additive Weighting (SAW).” JSiI (Jurnal Sistem Informasi) 4:19-24. 
Hermanto, Hermanto, and Nailul Izzah. 2018. "Sistem Pendukung Keputusan Pemilihan Motor Dengan Metode Simple Additive Weighting (SAW)." Matematika Dan Pembelajaran 6(2):184.

Juwita, Misna, Deddy Yusuf Yudhyarta, Kedisiplinan Mengajar, A. Pendahuluan, and Standar Nasional. 2020. "Mulyasa, E. Standar Kompetensi Dan Sertifikasi Guru, ( Bandung: PT Remaja Rosdakarya, 2009), Hlm. 17." 1(April):139-50.

Kurniawan, Arif. 2018. "Seri Sains Dan Teknologi IMPLEMENTASI SISTEM PENDUKUNG KEPUTUSAN PENENTUAN WARGA MISKIN MENGGUNAKAN METODE SIMPLE ADDITIVE WEIGHTING ( SAW ) Seri Sains Dan Teknologi E-ISSN 2615-4765." 4(2):72-77.

Latiana, Lita. 2010. "Peran Sertifikasi Guru Dalam Meningkatkan Profesionalisme Pendidik." Edukasi 0(3).

Malik, Ihyani. 2011. "Kebijakan Sertifikasi Guru (Tawaran Solusi Pendidikan Profesi Guru)." Otoritas : Jurnal Ilmu Pemerintahan 1(1):72-76.

Pendukung, Sistem, Keputusan Pemilihan, and Smartphone Menggunakan. 2018. "SEMINAR NASIONAL SISFOTEK." (September):4-5.

Priatna, Wowon, and Agung Nugroho. 2019. "Sistem Pendukung Keputusan Untuk Penentuan Dosen Favorit Menggunakan Simple Additive Weighting ( SAW )." (4):181-90.

Qowaid, Qowaid. 2015. "Pengaruh Sertifikasi Guru Terhadap Peningkatan Kinerja Guru Pai Di Smp Dan Mts." EDUKASI: Jurnal Penelitian Pendidikan Agama Dan Keagamaan 13(3):23-32.

Scobee, Richard G., and Howard C. Slaughter. 1944. "Endophthalmitis Phaco-Anaphylactica." American Journal of Ophthalmology 27(1):49-52.

Siahaan, Sudirman, and Rr. Martiningsih. 2018. "Seputar Sertifikasi Guru." Jurnal Teknodik 12(1):090.

Sistem, Jurnal. n.d. "Fakultas Ilmu Komputer."

Tusriyanto. 2014. "Serifikasi Guru Sebagai Upaya Menciptakan Mutu Pendidikan." Tarbawiyah 11(1):145-62.

Yusuf, Ningrum Fauziah, Herijanto Bekti, and Dedi Sukarno. 2017. "Implementasi Program Sertifikasi Guru Dalam Jabatan (Studi Pada Madrasah Aliyah Negeri Ciparay Kabupaten Bandung).” JANE - Jurnal Administrasi Negara 2(1):43-50.

Zul, Muhammad Ihsan, Politeknik Caltex Riau, Satria Perdana Arifin, and Politeknik Caltex Riau. 2016. "Sistem Pendukung Keputusan Untuk Pembelian Smartphone Menggunakan Metode Simple Additive Weight Dan Fuzzy Associative Memory." (June). 